Morozova 0.

\title{
DEVELOPMENT OF INNOVATIVE LEARNING TECHNOLOGY IN SYSTEMS WITH DUAL PROCESSES
}

В роботі запропонована розробка інноваційної технології навчання в системах з дуальними процесами. Об'єктом дослідження обрані інформаційно-технологічні процеси і явища, що виникають в системах з дуальними процесами. В ході дослідження запропоновано створення віртуальної студентської дослідноекспериментальної студії моделювання професійних знань. Одним з найбільш проблемних місць є створення і апробація иифрової платформи дисциплін за фахом. Дослідження передбачає в подальщому перехід від традиційних методів викладання до методів консалтингового формування професійних знань студентів за фахом на основі імітаційного моделювання. Завданнями студентів при ивому є розробка моделі дисииплін і формування їх індивідуальних моделей професійних знань за фахом. В ході дослідження використовувалися основи теорії систем для побудови методичної бази для розробки інноваційної технології навчання і методи статистики для оцінки можливості створення моделей професійних знань. Отримано інновачійну освітню технологію, яка має ряд особливостей. Зокрема, вона передбачає розробку моделі професійних знань, яка складається з безлічі вивчених дисциплін, практичних занять, технічних засобів навчання, оцінок і самооцінок, відносин між елементами моделі, темпоральних відносин. Запропоновано схему організацї̈ навчального процесу з використанням спеціально побудованої цифрової платформи знань. Показано порівняння традиційної схеми навчання та схеми навчання на основі цифрової платформи знань. Крім цього, в рамках досліджень проведена оцінка можливості створення моделей професійних знань, при цьому розрахунок узгодженості експертних оцінок проводився з використанням коефіщієнта конкордації Кендалла. Завдяки цвому забезпечується можливість отримання показників затребуваності запропонованої інноваційної технологї навчання в системах з дуальними процесами. Оцінки експертів показали, що створення студентами моделей професійних знань дозволить їм систематизувати свої знання в системах з дуальними процесами.

Ключові слова: інноваційна освітня технологія, системи з дуальними процесами, цифрова платформа знань, модель професійних знань.

\section{Introduction}

Modern education should be based on the following three principles: complexity, consistency and compliance with the requirements of employers to specialists. Today, Ukraine's higher education is constantly in a state of reorganization and modernization. In particular, this refers to the mechanisms for training specialists who are suitable for employment by profession. They have the latest knowledge, skills, and habits that match educational programs and production needs [1-3]. However, this training process must begin with the stage of education in general education institutions. Therefore, at present, special attention is paid to the development and improvement of forms and methods of administration of educational activities in educational systems. The priority direction of reforms that are taking place in the field of higher education is to increase the level of provision of educational services using modern information systems and technologies. In addition, a problem arises, namely, that students' professional knowledge is formed on the basis of studying a variety of different disciplines, including humanitarian, fundamental and professional. This leads to the use in the educational process of various mathematical apparatus and methods of knowledge representation, which are not always close to those that are necessary when solving production problems. There is a need to improve profes- sional knowledge and skills through the introduction of new forms of education [4]. One of the ways to solve this problem is the introduction of a dual system of vocational education and training, which is aimed at improving the level of professional training of personnel. It represents a new and more flexible form of organization of vocational training, which provides for coordinated interaction of the educational and production sphere in training qualified personnel of a certain profile within the functioning of educational complexes [5-7]. Therefore, the object of research is information technology processes and phenomena that occur in systems with dual processes. And the aim of research is the scientific substantiation of the feasibility of creating at the department of a higher educational institution a virtual student experimental experiment studio of modeling professional knowledge as an innovative educational technology in systems with dual processes.

\section{Methods of research}

The paper proposes an innovative educational technology in systems with educational and production processes (systems with dual processes), which involves the development of a model of professional knowledge (MPK). As part of the innovative educational technology, it is proposed to create a virtual student experimental knowledge modeling studio. The purpose of the creation of this studio for 
modeling professional knowledge is creation and testing a digital platform of disciplines in the specialty. In the future, it will be possible to move from traditional methods of learning to methods of consulting the formation of students' professional knowledge in their specialty based on simulation modeling $[8,9]$. The task of scientific and pedagogical workers (SPW) is the following: on the basis of the requirements of the standards, create a model of an academic discipline, the information of which should be the basis (source data) for the formation of models of students' professional knowledge. At the same time, the tasks of students are that, based on the structure and use of a high level of generalization of information provided by teachers, develop discipline models and form their individual models of professional knowledge in the specialty (knowledge atlases).

The model of professional knowledge is based on the following formula:

$$
M_{P K}^{S N P}=\langle D, P, S, O, \Omega, T\rangle,
$$

where $M_{P K}^{S N P}$ - individual (surname, name, patronymic) model of the student's professional knowledge; $D$ - set of studied disciplines; $P$ - set of practical exercises, including practice; $S$ - set of technical training tools; $O$ - set of assessments and self-assessments; $\Omega$ - set of relationships between elements; $d \in D, p \in P, s \in S$; $T$ - set of temporal relationships that are formed between the sets of the model.

In addition, the scheme of the organization of the educational process using a specially constructed digital knowledge platform (DKP) is proposed, which is shown in Fig. 1.

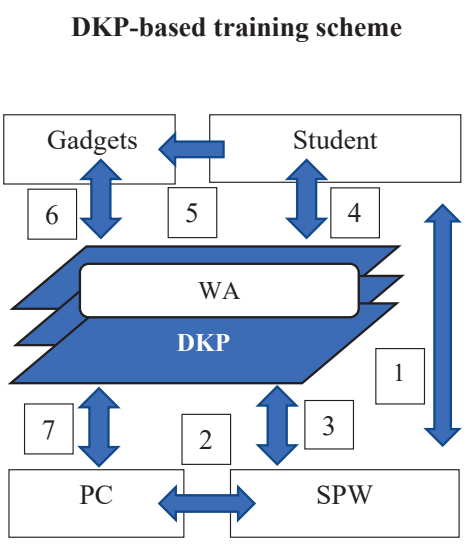

Traditional training scheme

Fig. 1. Schemes of traditional education and learning based on the digital knowledge platform (DKP)

Fig. 1 indicates the following types of communications traditional learning scheme:

PC - personal computer;

SPW - scientific and pedagogical workers;

1 - speech communication between the SPW and students in the form of a lecture;

2 - formation of graphic and formal elements of educational material;

3 - formation by students of an image of educational material based on graphic and formal representations of educational material;

4 - formation of a model of educational material in the form of lecture notes;
5 - formation of the SPW model of the educational material of the discipline.

DKP-based training scheme:

WA - working area;

PC - personal computer;

SPW - scientific and pedagogical workers;

DKP - digital knowledge platform;

1 - speech communication between the SPW and students in the form of consultations;

2 - formation of the SPW model of educational discipline on the PC;

3 - transfer of the model of the discipline of the SPW in the WA;

4 - student's study of the model of the discipline placed in the WA;

5 - formation of the individual model of the discipline by the student on the basis of the studied material;

6 - placement of an individual model of knowledge formed by the student on the basis of their gadgets in the WA;

7 - SPW analysis of individual models of students' knowledge of the studied discipline and the creation of a generalized model that takes into account the proposals of students.

\section{Research results and discussion}

To assess the possibility of creating models of professional knowledge, in the fall semester of 2018/2019, students of the 2nd and 4th year of the department of land administration and geographic information systems of the O. Beketov Kharkiv National University of Urban Economy (Ukraine) were given the task to build their individual knowledge model.

Verification of the work at the end of the semester shows that each student, in varying degrees, coped with the task. A preliminary analysis of 70 students' works shows that their quality lies in a large range. To create a methodology for expert assessment of the models of professional knowledge of individual students, a questionnaire is developed, which includes the following criteria:

1. To what extent is the model showing the relationship between knowledge and competences (skills)? Measuring range [0, 100].

2. To what extent are technical learning tools displayed in the model? Measuring range $[0,100]$.

3. To what extent is the criticism of the organization of the educational process reflected? Measuring range [0, 100].

4. To what extent is the self-assessment of the learning process reflected? Measuring range [0, 100].

5. To what extent is the connection between the main elements of the educational process displayed? Measuring range $[0,100]$.

6. To what extent are the temporal relations reflected in the model between its main elements? Measuring range $[0,100]$.

7. In addition, it is suggested that they express their views on developed models of professional knowledge:

a) is the proposed formula for constructing a MPK complete for the formation of a knowledge model? Implies the views of the evaluator; 
b) how do you think, will students motivate the process of creating and maintaining a MPK to improve the qualitative and quantitative indicators of learning the study material? With variants of the answer: «YES» or «NO».

The calculation of the consistency of expert estimates is carried out using Kendall's concordance coefficient [10]:

$$
W=\frac{12 S}{m^{2}\left(n^{3}-n\right)},
$$

where $m$ - the number of experts in the group; $n$ - the number of factors; $S$ - the sum of squares of rank differences (deviations from the mean), which is calculated according to the formula:

$$
S=\sum_{j=1}^{n}\left(\sum_{i=1}^{m} A_{i j}-\frac{1}{2} m(n+1)\right)^{2},
$$

where $A_{i j}$ - an element of the considered population.

Assessing experts were divided into two classes according to the experience of scientific and pedagogical activity: class 1 - work experience from 5 to 15 years, class 2 - work experience from 15 to 50 years.

In their assessments, the experts agreed that the creation by students of models of professional knowledge will allow them to systematize their knowledge in systems with educational and production processes.

\section{Conclusions}

The results of theoretical and experimental studies conducted at the Department of Land Administration and Geographic Information Systems of O. Beketov Kharkiv National University of Urban Economy (Ukraine) show the possibility of creating a digital knowledge platform at the department, as well as atlases of students' professional knowledge.

For additional research and creation of a working digital knowledge platform it is proposed to create a student virtual experimental knowledge modeling studio at the department.

In the future, it is proposed to develop and test the technology of consulting formation of students' professional knowledge in their specialty in systems with educational and production processes. Testing is possible on the basis of special methodological support covering the majority of academic disciplines. In addition, models of professional knowledge and academic disciplines developed by students and teachers will be used.

\section{References}

1. Meteshkin K. A. Kiberneticheskaya pedagogika: teoreticheskie osnovy upravleniya obrazovaniem na baze integrirovannogo intellekta: monograph. Kharkiv: Mezhdunarodnyy slavyanskiy universitet, 2004. 400 p.

2. Kiberneticheskaya pedagogika: ontologicheskiy inzhiniring $\mathrm{v}$ obuchenii i obrazovanii: monograph / Meteshkin K. A., Morozova O. I., Fedorchenko L. A., Khayrova N. F. Kharkiv: KHNAGKH, 2012. 207 p.

3. Konysheva A. V., Ibragimova E. N. Training of Engineers in Mathematics at University on the Basis of the Information Cybernetic Approach // Eurasia Journal of Mathematics, Science and Technology Education. 2017. Vol. 13, Issue 8. P. 4379-4391. doi: http://doi.org/10.12973/eurasia.2017.00933a

4. Manako A. F., Sinitsa E. M. Informatsionnye tekhnologii v obrazovanii // Upravlyayushhie sistemy i mashiny. 2017. Issue 2. P. $46-57$.

5. Martin B., Mitroic A. Automatic problem generation in constraint-based tutors // Intelligent Tutoring Systems. Springer Berlin Heidelberg, 2002. P. 388-389. doi: http://doi.org/10.1007/ 3-540-47987-2 42

6. Savin-Baden $\bar{M}$. A practical guide to problem-based learning online. New York: Routledge, 2007. 151 p. doi: http://doi.org/ 10.4324/9780203938140

7. Christensen C. M., Eyring H. J. The innovative university: Changing the DNA of higher education from the inside out. San Francisco: Jossey-Bass, 2011. 512 p.

8. Greasley A. Simulation modelling for business. Routledge, 2017. 230 p. doi: http://doi.org/10.4324/9781315243085

9. Macal C. M. Everything you need to know about agent-based modelling and simulation // Journal of Simulation. 2016. Vol. 10, Issue 2. P. 144-156. doi: http://doi.org/10.1057/jos.2016.7

10. Prigarina T. A., Chebotarev P. Yu. Ekspertnye otsenki v sotsiologicheskikh issledovaniyakh / ed. by Krymskiy S. B. Kyiv: Naukova Dumka, 1990. P. 190-225.

Morozova Olga, PhD, Associate Professor, Department of Theoretical Mechanics, Mechanical Engineering and Robotic Systems, Zhukovsky National Aerospace University «Kharkiv Aviation Institute», Ukraine, e-mail: oligmorozova@gmail.com, ORCID: http:// orcid.org/0000-0001-7706-3155 